\title{
Zen-Boeddhistiese selfloosheid as sentrale interteks van die Breytenbach-oeuvre
}

\author{
Abstract \\ The aim of this anticle is twofold: \\ - To postulate the Buddhist notion of selflessness as central to the art and writing of Breyten \\ Breytenbach. \\ - To provide an overview of the philosophy this implies and of the way in which it offers a reading of \\ the Breytenbach-oeuvre.
}

The Buddhist concept of selflessness as expressed in the work of Breytenbach is by way of contrast firstly set against the background of the more familiar Western philosophical tradition, and then analysed within the context of Buddhist experiences such as Sunyata, Satori, Zazen and the Taoist principle of relativity to which it is inexorably linked. In doing so an attempt is made to fulfil a need that became apparant from discussions with colleagues and (post)graduate students: Although Zen-Buddhism in general has long been accepted as a primary intertext of the Breytenbach oeuvre, and although it is common practice to nefer to notions such as Satori, Zazen and the Void when studying his work, it is not always clear in which way the Buddhist philosophy is pertinent to the creative process as such, be it that of creative writing or painting. To constue the presence of Buddhist terminoloy in the Breytenbach text as a mere tool for the unfolding of plot or as an attempt to define his writing as moralistic or mystical is an unfortunate misconception. In addition to the focus on Buddhist selflessness and the way in which it is reflected in Bneytenbach's work, this article therefore offers some suggestions on the way in which an understanding of Buddhist principles can serve as elucidation of the nature of the Breytenbach oeuvre and the creative experience as such.

\section{Doelstelling}

By geleentheid het Breyten Breytenbach hom soos volg uitgespreek oor die selfloosheid van die 'ek' in skilderkuns en poësie; die feit dat die 'ek' slegs 'n medium, 'n filter vir waarneming is:

... an element of Zen that comes into poetry and painting (...) is the dissolution of the so-called 'self, the ' $I$ '. The 'I' becomes an observation point, a point of passage, through which the images and the perceptions move. You become part of your work, the way the archer and target and the arrow eventually become one. Because underlying Zen Buddhism, there is this notion of the non-being of the ' $\mathrm{l}$ ', the non-exclusivity of the ' $\mathrm{l}$ '. The fact that one is a changing collection of elements, and that what you strive towards, is to move through the exploration, through the deepening of perception, to the dissolution of that. To stop being, and to be for always, as it were (Breytenbach tydens 'n radioonderhoud, 9 Februaric 1992). 
Dit word lank reeds aanvaar dat die Zen-Boeddhisme oor die algemeen 'n primêre interteks is in Breyten Breytenbach se oeuvre. In hierdie artikel word egter aangevoer dat spesifiek die Zen-Boeddhistiese siening van selfloosheid sentraal staan in die Breytenbachoeuvre, en dat begrip van die aard en implikasie daarvan noodsaaklik is vir enige ondersoek van sy werk. Omdat die kwessie van selfloosheid moeilik in isolasie beskou kan word, word dit eerstens by wyse van kontras geplaas teen die agtergrond van die tradisionele Westerse siening van selfloosheid. Tweedens word die manier waarop dit in die Breytenbach-oeuvre gemanifesteer word, binne die konteks van Zen-beginsels soos Sunyata, Zazen, Satori en die Taoïstiese beginsel van relatiwiteit ondersoek. Uit gesprekke met kollegas en (na-graadse) studente skyn daar 'n behoefte te wees aan 'n kernagtige uiteensetting van hierdie beginsels en die manier waarop die filosofiese strekking daarvan gekoppel kan word aan 'n moderne literêr-teoretiese benadering. Hoewel dié ondersoekterrein baie wyd is en daar binne die bestek van hierdie artikel slegs tentatiewe voorstelle gemaak kan word, hoop ek om hiermee ten dele aan dié behoefte te voorsien. Die bedoeling is om oorsigtelik te werk te gaan en alleenlik dié aspekte uit te lig wat betrekking het op Breytenbach.

\section{Die tradisionele Westerse ego- of selfkonsep}

Slegs enkele aspekte wat relevant is vir die huidige ondersoek word hier uitgelig. Volgens die moderne (dit wil sê sedert die $17 \mathrm{de}$ eeu en verder) Westerse filosofie spruit die 'ek'- of ego-identiteit uit die oortuiging dat die individu as afsonderlike, aparte entiteit optree en as subjek van sy eie handeling inwerk op sy omgewing. As waarnemingsubjek word die ego beskou as 'n vaste punt of 'n sentrum waarvolgens betekenis aan die wêreld gegee word. Deur middel van die verstand en die sintuie raak so 'n subjek bewus van homself as enkeling, en bestaan daar 'n definitiewe verwydering tussen die individu en sy omgewing.

Descartes se cogito ergo sum vorm die basis van die veronderstelling dat die liggaam en die gees van mekaar geskei is. Rasionele denke is die enigste voorwaarde vir die daarstelling van ego-identiteit. Die siening dat die verstand geskei is van die liggaam impliseer voorts dat die verstand ook geskei is van materialiteit, want dit is deur die liggaam se sintuie dat 'n mens kommunikeer met die materiële wêreld en die mense om jou. Dit is eweneens deur die liggaam se sterflikheid dat jy deel in die verbygaande aard van alle dinge, en dat die geskiedenis binne liniêre tydsverband ontplooi. Geskei van die materiële wêreld word die mens se gedagtes en sy idees die objek van sy 'kennis'.

Die verstand is die maatstaf waardeur alles geken en beheer kan word. Omdat die verstand net dít kan ken wat intellektueel waarneembaar en hanteerbaar is, impliseer egoidentiteit 'n digotomie van subjek-objek waaruit geen uitkoms moontlik is nie. Die absolute waarde wat aan die verstand geheg word, impliseer dat net dít wat geken kan word, werklik bestaan. Die veronderstelling word dan voorts gemaak dat $e k$ is omdat ek myself ken, en word die sogenaamde ego-identiteit ervaar as 'n konstante struktuur wat dwarsdeur 'n mens se lewe min of meer stabiel is. Vandaar ook die aanvaarding (wat problematies is vanweë bogenoemde digotomie) dat 'n persoon se biografie die beskrywing is van sy bepaalde historiese persoonlikheid en sy interaksie met die materiële omgewing. Die implisiete selfbeeld of ego-identiteit word dus veruiterlik deur konkrete wisselwerking met die wêreld daarbuite, (of soms ook net deur die herinnering aan hierdie interaksie) en skyn as geslote, afgeronde totaliteit op te tree. 
'n Variant van die moderne 'self', nader aan die Hegeliaanse-Marxistiese opvatting, is dat ego-identiteit as definieerbare totaliteit waardeur die individu homself teenwoordig stel, tot 'n groot mate gevorm word deur wisselwerking met die gemeenskap. Wat 'n individu 'is', word bemiddel deur sy omgewing. "The individual can experience himself indirectly by the reaction of others towards him, he encounters the self in social activity, i.e. communication of any kind" (Golz,1989:29). Die eksplisiete ego-identiteit word in stand gehou deur kommunikasie met ander, hetsy in die vorm van gesprek, gebaar, geskrif, beeldende kunswerk, en so meer. Volgens Hegel verkeer die 'self' en die gemeenskap in 'n dialekties wederkerige verhouding: anders as by Descartes is selfbewussyn hier iets wat deur die gemeenskap bemiddel word.

Dit is in hierdie verband duidelik dat 'n persoon in eensame opsluiting, soos in Breytenbach se geval, sal moet staatmaak op die herinnering aan interaksie met die wêreld daarbuite, en dat sy behoefte om binne die tronksituasie skeppende skryfwerk te doen 'n poging is om te kompenseer vir die wegskilfer van stabiele ego-identiteit wat deur enige persoon onder soortgelyke omstandighede ervaar word. Die versplinterde struktuur van Mouroir (1983a) verbeeld byvoorbeeld hierdie probleem, en die gefragmenteerdheid wat deur die subtitel ("bespieëlende notas van 'n roman") gesuggereer word, is 'n metafoor van die gevangene se indentiteitskrisis (kyk Golz, 1989:69-129 vir 'n deurdringende analise hiervan, asook Botha, 1988:5-22).

Van primêre belang dus vir die skryf- of skilderkuns is dat die kunswerk as 'n materiële produk van die geheue as denkapparaat beskou word, en die doel dien om konkreetheid te verskaf aan die skrywer/kunstenaar se implisiete ego-identiteit. Laasgenoemde is dan ook die tradisionele, konvensionele siening van kuns en poësie, naamlik die vaslê van die subjek se ego-identiteit binne die kunswerk: "puesto que miro, escribo y escucho no estoy muerto" ('omdat ek waarneem, skryf en luister is ek nie dood nie' [M.S.] ), skryf die Spaanse digter Rafael Alberti, 1988:489).

Hegel se kritiek van Descartes se cogito berei die weg vir die moderne filosofiese siening van selfbewussyn waarvolgens subjektiwiteit nie buite berekening gelaat kan word nie. Soos blyk uit onder andere die Surrealisme het die teorieë van Freud die siening van 'n objektiewe, onveranderlike ego-identiteit heeltemal omvergewerp deur sy omskrywing van die onbewuste. Soos getuig in drome en sogenaamde slips of the tongue is die mens uitgelewer aan die intuiitiewe, instinktiewe magte van die onbewuste waaroor hy nie beheer het nie; wat hy met ander woorde nie op die Cartesiaanse manier kan kén nie. Hierdie ontdekking het dramatiese veranderinge in die kuns en letterkunde van die 20 ste eeu teweeggebring, waarvan die Surrealiste se écriture automatique net een voorbeeld is. Vanuit bogaande breë raamwerk word vervolgens 'n Westerse interpretasie van die ZenBoeddhistiese siening van die 'self' gegee. Geen aanspraak op diepte-navorsing oor die Boeddhisme as sodanig word dus hier gemaak nie.

\section{Die Zen-Boeddhistiese siening van die 'self'}

Omdat 'n magdom literatuur oor die Zen-Boeddhisme algemeen beskikbaar is, en omdat dit hier spesifiek gaan oor die toepassing daarvan op die kreatiewe skryf- en skilderproses, word hier geen aanspraak op 'n geheelbeeld van dié Oosterse filosofiese tradisie gemaak nie. Slegs die volgende aspekte van die Soto-skool (waaronder Breyten hom skaar, kyk Boek,1987:74) en waarsonder geen werklike vashouplek aan sy oeuvre moontlik is nie, 
word hier belig:

- Die beskouing van kennis.

* Die beginsel van relatiwiteit.

* Die Groot Niet.

* Zazen as Satori.

* Die 'self'.

Bogaande aspekte van Zen word hier ter wille van helderheid afsonderlik beskou. Daar moet dus in gedagte gehou word dat die een van die ander afhanklik is en 'n mate van oorvleueling onvermydelik is.

Dit is belangrik om Zen histories binne die konteks van die Taoïsme en Mahayana Boeddhisme te plaas, omdat spore daarvan neerslag vind in Breytenbach se siening van selfbewussyn. Daarom sal enkele aspekte van die Taoïsme en Boeddhisme oorsigtelik bespreek word. (Kyk ook Breytenbach, 1987:72-79.)

\subsection{Sjinese Taoïsme}

Die eeue-oue Sjinese Taoïsme het met die Mahayana Boeddhisme van Indië gekombineer om teen ongeveer die 13de eeu in Japan uit te blom as Zen (Ch'an genoem in Sjina) (Watts, 1957:47). Soos vergestalt in Zen, werp albei hierdie filosofiese strominge lig op die Breytenbach-oeuvre, en is dit noodsaaklik om daarvan kennis te neem in 'n poging om sy werk sinvol te interpreteer. In verband met Tao dus kortliks die volgende:

The Tao is that from which one cannot deviate;

that from which one can deviate is not the Tao

(Chung Yung soos aangehaal deur Watts, 1975:37).

Tao is dus dit waaruit die ganse heelal en alles daarin bestaan. 'n Mens kan gevolglik nie daarvan afwyk nie; alles is die Tao, ook genoem die Weg (soms beskryf as "cosmic process", kyk Hofmeyr, 1991:111). Hierdie siening impliseer voorts dat die heelal bestaan uit polariteite wat in voortdurende wisselwerking met mekaar staan, en dus in 'n nimmereindigende toestand van transformasie verkeer: "... seen as a whole the universe is a harmony or symbiosis of patterns which cannot exist without each other" (Watts, 1975:51). Hierdie siening word beskryf as 'n "transactional view of the world" (Watts, 1975:53), gebaseer op die beginsel van hsiang sheng ("mutual arising") waarvolgens ons bewussyn die heelal 'produseer', en die heelal op sy beurt weer ons bewussyn daarstel.

Die enigste geskrewe bron van die Taoïsme is die Tao-te-ching, volgens oorlewering die werk van die waarskynlik legendariese wysgeer Lao-Tzu, en hierdie antieke geskrewe bron beklemtoon reeds in die aanvangsreëls die gedagte dat die oorsprong of kern van die heelal 'n proses, en nie 'n wese is nie, en dat dit hoegenaamd nie beskryf of benoem kan word nie.

The Tao that can be told of is not the eternal Tao;

The name that can be named is not the eternal name.

The nameless is the origin of Heaven and carth;

The named is the mother of things

(soos vertaal in Hofmeyr, 1991:111).

Die laaste reël in die aanhaling suggereer dat ons waarneming van die heelal as bestaande 
uit gedifferensieerde objekte (in plaas van as enkele, harmonieuse proses), toegeskryf moet word aan die feit dat ons dinge benoem. Daar word elders in die artikel hierop uitgebrei. Die harmonie van die Tao as kreatiewe krag spruit uit die gebalanseerde interaksie van die Yin- en die Yang-polariteite:

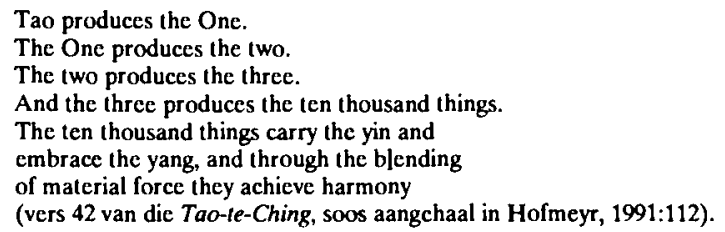

"The two" verwys na die Yin- en Yang-polariteite inherent aan die Tao, wat soos met biologiese of fisiologiese voortplanting, die "ten thousand things" laat ontstaan, dit wil sê die differensiasie waarneembaar in die materiële wêreld. Wat bedoel word met "the One" word gevind in vers 40 van die Tao-te-Ching:

\section{All things in the world come from being \\ And being comes from non-being}

(Hofmeyr 1991:112).

Hier vind ons die vernaamste onderskeidende kenmerk van die Taö̈sme, naamlik dat die kern of bron van die heelal nie ' $n$ Wese is nie, maar "non-being". Die Tao is soos 'n enorme leë ruimte waarbinne dinge ontstaan, op mekaar inwerk en sterf. "As spaciousness the Tao is undifferentiated, but the two together - that is, the space on the one hand, and the collection of the ten thousand things interacting on the other - are the one world process" (Hofmeyr, 1991:112). Die "Een" van Tao verwys dus na hierdie konsep van die heelal as enkele proses:

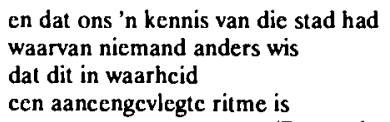

(Breytenbach, 1984a:68).

'n Taoïstiese lewensbenadering impliseer drie beginsels: wu-wei (geen aksie); wu-hsin (geen intellektuele beredenering); en $t z u$-jan (spontaneïteit). In die bespreking oor Zen word hierop uitgebrei. Vloeiende water word meestal as metafoor gebruik om hierdie lewenshouding te beskryf; die lewe moet sy eie gang gaan, want daar word geglo dat die Tao in elk geval inherent positief en harmonieus is. Die talle waterverwante beelde in die Breytenbach-oeuvre weerspieël dikwels hierdie vloeiende krag van die Tao: dit is die "droomstroom" (Breytenbach, 1983b:3,4 en 134) van kreatiwiteit.

\subsection{Die Indiese Mayahana Boeddhisme}

Die Indiese Mayahana Boeddhisme wat as voedingsbodem van Zen by Taoïsme aansluit, word gekenmerk deur die leerstelling van 'leegheid' (Sunyata). Van belang vir die huidige studie is die Mahayana-siening dat hierdie leegheid die beste deur middel van meditasie ervaar kan word. (Later meer hieroor.) In teenstelling met die Westerse opvatting van 'leegheid' beteken Sunyata hoegenaamd nie dat niks bestaan nie, en dit is heeltemal foutief om dit as nihilisties te interpreteer. Wat dit wél impliseer is dat 'ek' nie op permanensie 
aanspraak kan maak nie en ook nie as aparte, identifiseerbare entiteit bestaan nie. Die heelal moet alleenlik as proses, as voortdurend in beweging, beskou word. Daar is dus niks wat standhoudend van een moment na die volgende voortduur nie. Sunyata word met 'n vlam vergelyk (Hofmeyr, 1991:91): soos vuur het dit kontinuïteit, maar geen deel daarvan het permanensie of identiteit nie. Vandaar ook die aanhaling "om te lewe is om te brand" wat Breytenbach as titel kies van die slotgedig in Eklips (1983:102).

Die mens se onvermoë om tot hierdie besef deur te dring is inherent aan sy konsepsuele manier van dink: dit is as gevolg van menslike konsepte en die aard van taal dat ons die wêreld as onveranderlik of permanent ervaar, die "konsepsies wat belemmerend en beslommerend is" (Breytenbach, 1987:76). Ons gebruik woorde en konsepte om te verwys na verbygaande, onvasvangbare verskynsels, en sodoende word die illusie van stabiele realiteit geskep. Die leerstelling van Sunyata beteken nie dat die heelal of die Waarheid 'leeg' is nie, want leegheid bly 'n konsep, en konsepsualisme moet deurbreek of getransendeer word. Vandaar die woorde van die Hart-Soetra wat Breytenbach aan die begin van ("Yk") aanhaal: "Verby, verby, anderkant verby, heeltemal verby anderkant, o wat 'n ontwaking, alle heil!" (waar "heil" die betekenis van verlossing het). Hierdie gewaarwording word genoem sunyatasunyata (Williams, 1989:63) wat as 'die leegheid van leegheid' vertaal word. Met Sunyata bereik mens dié punt waar hy niks meer aankleef nie, nóg intellektueel nog materieel; " (... ) for the function of understanding emptiness is simply to cut out grasping" (Williams, 1989:63). Vir die Boeddhis impliseer 'heil' (verlossing) dus die vermoë tot 'geen verkleefdheid' wat spruit uit die besef dat daar niks is om aan te kleef nie. Hierdie siening sluit aan by die Taoïstiese ineenvloeiing van die self met die cosmic process.

So ver dan wat betref die twee vername strominge (Taoïsme en Mahayana Boeddhisme) wat die voedingsbodem is van die Zen-Boeddhisme in Japan of Ch'an soos dit in Sjina genoem word. Albei woorde is afgelei van die Sanskrit dhyana, wat 'meditasie' beteken (Williams, 1989:113).

\subsubsection{Zen-Boeddhisme}

Zen-Boeddhisme is nie 'n monolitiese filosofie nie en word verdeel in die Rinzai-skool en die Soto-skool, waar eersgenoemde gekenmerk word deur die gebruik van koan (raaisels) om skielike, bruuske Satori (ontwaking) te bereik. Hoewel Breyten homself nie hierby skaar nie, maak hy soms wel gebruik van die beelding en terminologie wat tipies is van die koan, soos byvoorbeeld "What did you look like before you or your father or your mother were born?" (Breytenbach, 1984b:13).

Dit is veral die Rinzai-skool wat in die Weste redelike bekendheid verwerf het deur die vestiging van Zen-meesters in Amerika, Engeland en Europa, en ook deur die wye verspreiding van publikasies (veral deur Suzuki en Watts) wat gerig was op die leek. Veral in die sestigerjare het Zen groot aanhang geniet onder die jeug; vandaar dan ook die simplistiese siening daarvan as argaïese oorblyfsel van 'n vergange hippiekultus. Dit is wel so dat sekere aspekte van Zen deur individue verdraai en vir eie gewin gemanipuleer is, soos byvoorbeeld dat die gebruik van dwelmmiddels 'n kortpad bied na Satori wat andersins net deur die dissipline van meditasie ervaar kan word. Maar soos Breyten dit stel: "die hippies sit die ketel mis" (1987:171). Hierdie wanopvatting maak 'n uiteensetting van Zen-beginsels, wat primêr staan in die Breytenbach-oeuvre, des te dringender. Hierdie studie gaan nie oor die morele regverdiging of mistieke waarde van Zen as voedingsbron 
van die Breytenbach-oeuvre nie, maar wel oor die implikasies daarvan vir die aard van sy werk en die kreatiewe skryf- en skilderproses oor die algemeen.

Die Soto-skool wat gestig is deur die filosoof en digter Dogen (1200-53), lê klem op die waarde van Zazen (meditasie). Binne die konteks van Breytenbach se kenmerkende en ongewone skryfstyl, is dit insiggewend dat Dogen sy beroemde geskrifte oor die Boeddha Dharma in Japanees geskryf het waarin hy, in teenstelling met die konvensies van sy tyd, vrylik gebruik maak van Sjinese terme en alledaagse spreektaal. Die dikwels ontoeganklike styl van Breytenbach word onwillekeurig opgeroep wanneer Abe (1985:26) met verwysing na Dogen sê:

The difficult and unique style of his Japanese writing is derived from the fact that, in expressing his own awakening, he never used conventional terminology, but employed a vivid, personal style grounded in his subjective realization. Even when he used traditional Buddhist phrases, passages, etc., he interpreted them in unusual ways in order to express the truth as he understood it.

Soos in die geval van al die Boeddhistiese skole word konseptuele denkprosesse in sowel die Rinzai- as die Soto-skole oorskry, en alles berus uiteindelik op die individu se eksistensiële ervaring van die werklikheid. As gevolg van die klem op ervaring word daar in Zen egter tot 'n mindere mate gesteun op geskrewe dogma en soetras.

Die vernaamste aspekte van die Zen Soto-skool wat die kwessie van die 'self' in die Breytenbach-oeuvre sowel as sy beeldgebruik oor die algemeen belig, word vervolgens van nader beskou:

\title{
3.3 Die Zen-Boeddhistiese beskouing van kennis
}

\author{
die dink/bedink moct verslyt \\ tot net die hef oorbly voor jy \\ met dáádic lem deur die wortel kan by
}

(Breytenbach 1984a:156).

In Zen word daar nie, soos dikwels verkeerdelik gemeen, weggedoen met die intellek nie. Die term wu-hsin (Watts, 1957:160) wat hierdie aspek van die Zen-Boeddhisme omskryf is dus geensins anti-intellektueel of 'n ontkenning van die waarde van denke nie. Die intellek of 'n denkwyse gebaseer op konsepte en kategorieë word wel getransendeer, en intuïtiewe ervaring waarby die wese in sy geheel betrek word, word as ideaal voorgehou. Hiermee word bedoel dat buite-sintuiglike, bo-diskursiewe meditatiewe kenvermoëns beklemtoon word. Die doel van kennis is nie intellektuele bevrediging of prestasie nie, maar wel ware kennis wat lei na verlossing wat alreeds ontologies verwerklik is deur middel van die individuele en ontologiese beginsel van selfloosheid/leegheid/Sunyata (soos uiteengesit in die bogaande oorsig van Taoïsme en Mahayana Boeddhisme). Dit is hierdie intuïsie wat Breytenbach (1983b:5) beskryf as "oopstelling, oplossing, verwatering van gewaande begrensde 'ek' en 'jy' ".

Die Hindoeïstiese siening van die 'ek' wat deur middel van die intellek tot stand kom en wat vir die Hindoe sowel as vir die Boeddhis (kyk Versfeld, 1991:162) in die weg staan van ware intuïsie, kan hier verhelderend wees. Hiervolgens moet onderskeid gemaak word tussen die verstand (mind) en Purusa (Spirit). Die verstand behels naamlik drie komponente, manas, buddhi en ahamkara. Manas is die verstand se vermoë om deur middel van sintuie prikkels uit die omgewing op te neem. Buddhi is die vermoë om hierdie sintuiglike 
indrukke te klassifiseer en om daarop te reageer, soos byvoorbeeld om te besluit dat iets aangenaam is en dit dan na te streef. Ahamkara is die vorming van 'n ego-konsep, wat bogenoemde indrukke toe-eien as sy eie, byvoorbeeld die idee dat 'ek' iets aangenaams ervaar, of dat 'ek' die klok hoor lui, en wat hierdie indrukke deur middel van die geheue bewaar as 'my' kennis, 'my' ervaring. Hoewel die verstand vir die Westerling bewus en intelligent skyn te wees, is dit egter vir die Oosterling net 'n illusie: die verstand het slegs 'geleende' of sekondêre intelligensie en bewussyn. Purusa of suiwer bewussyn is die ware subjek van bewussyn, en kan nie geken word nie. Net soos wat die hand homself nie kan aangryp nie, en die oog homself nie kan waarneem nie, net so kan die verstand homself ook nie begryp nie. Omdat ons die ego deur middel van die verstand daarstel, is dit slegs 'n parodie van die Purusa, en is dit by uitstek dié hindernis wat in die weg staan vir die bereiking van Satori.

\section{In die "Lankavatara Soetra" staan:}

Transcendental intelligence rises when the intellectual mind reaches its limit and, if things are to be realised in their true and essence nature, its processes of mentation (...) must be transcended by an appeal to some higher faculty of cognition. There is such a faculty in the intuitive mind, which (...) is the link between the intellectual mind and the Universal Mind (soos vertaal in Hoover, 1988:45).

Om hierdie rede is dit belangrik om nie deur stellings soos "Zen as the religion of the antirational" (Hoover, 1988:4) mislei te word nie. Die Rinzai-skool se gebruik van koan of irrasionele raaisels om Satori of Verheldering te bereik is veral verantwoordelik vir die wanopvatting dat Zen irrasioneel en anti-intellektueel is. 'n Voorbeeld van so 'n koan is "wat is die skyn van jou Oorspronklike Gelaat?" (kyk Watts, 1957:104) of "watter geluid word deur die geklap van een hand voortgebring?" (kyk Dumoulin, 1963:257). Die Zennis is veronderstel om te konsentreer op hierdie soort vraag waarop die intellek duidelik geen rasionele antwoord kan vind nie. Hierdeur word hy tot die besef gedwing dat die intellek as instrument tot Satori ontoereikend is en getransendeer moet word, sodat die 'Werklikheid' op ' $n$ intuïtiewe manier beleef kan word. Hierdie houding herinner aan die Taoïsme wat so sterk klem plaas op "an original, non-conceptual spontaneous purity beyond all words" (Williams, 1989:76).

Die waarde wat Zen plaas op die intuïtiewe vermoëns, sluit aan by die transendering van die intellek. Breytenbach self keer telkens terug na die noodsaaklikheid van intuïtiewe ervaring; "slegs intuïsie kan verder as rede gaan" (1987:26) en beklemtoon veral die verband daarvan met inspirasie wat lei tot die skeppingsdaad, waar "jy die intuïtiewe aanvoeling van jou wese verskerp en die 'redelike' na ontleding en opweging opsy skuif ..." (1987:78-79). Suzuki (1957:62) vergelyk die mens se intuïtiewe vermoëns met die oopgaan van 'n derde oog waardeur kreatiwiteit in werking gestel word: "Until you have a third eye opened to see into the inmost secret of things, you cannot be in the company of the ancient sages." Hierdie uitspraak herinner aan die selfportret van Breytenbach agter op die boekomslag van ("Yk"), waar die gapende wond op sy voorkop as 'derde oog' die skeppende krag van die bundel suggereer.

\subsection{Die beginsel van relatiwiteit}

(...) alles wat kom

en gekom het moet weer gaan - die wet

van die weters en die knersers van tandvleise

(Breytenbach, 1984 a:159). 
Hierdie beginsel word miskien die beste by wyse van kontras met die Westerse siening geillustreer. Onlosmaaklik verbind aan die vertroue wat in die Weste geplaas word op die vermoëns van die intellek of logika, is die konseptuele denkwyse of manier van 'sien'. Die Westerling is geneig om alles in terme van teenstellende kategorieë te beskou. So word 'goed' as die teenpool van 'kwaad' beskou, 'wit' as die teenoorgestelde van 'swart' en so meer. Hierdie konseptuele manier van sien hou per slot van sake verband met die aard van taal, waar ' $n$ woord of betekenaar veronderstel is om 'n spesifieke, afgebakende konsep of betekende aan te toon. In Boek (1987:78) word Blyth aangehaal:

... the use of paradox (...) arises from the inability of language to say two things at once. Paradoxes are the bright banners of the liberty of the mind ... Reason grips life with a strangle-hold, but life says,

'To win is to loose', and as in Judo, 'uses the power of the enemy to escape from it'.

Die afleiding wat hier gemaak word is dat dualiteit of oënskynlike paradoks 'n produk van die intellek is, wat nie noodwendig toegang tot die 'werklikheid'verleen nie (Watts, 1957:93).

Zen deurbreek hierdie soort intellektuele waarneming van alles in terme van kategorieë, niê deur die bestaan van die verskillende konsepte te ontken nie, maar deur dit te sien as twee pole van een en dieselfde saak, soos die twee kante van een en dieselfde vel papier:

so is die onversadigbare gang van verval die onverstuitbare ontluiking van dic blom

(Breytenbach, 1985:16).

of elders:

$$
\begin{aligned}
& \text { Lewe en dood is kif-kif, } \\
& \text { twee skywe van dieselfde sigaret, } \\
& \text { witvinger en as van dieselfde proses, } \\
& \text { binnekant en buitekant van dieselfde niet }
\end{aligned}
$$

(Breytenbach, 1987:60).

Dit is egter 'n polariteit wat impliseer dat albei pole nodig is vir die daarstelling van die meganisme, en dat hulle in spanning of balans verkeer met mekaar, nie in konflik nie. Dit is dieselfde beginsel waarvolgens ' $n$ voorwerp alleenlik sigbaar word omdat dit in vorm of kleur kontrasteer met sy omgewing, soos byvoorbeeld 'n geel vel papier wat uitstaan wanneer dit teen 'n donkerblou gekleurde agtergrond gehou word. Dieselfde vel papier 'verdwyn' egter as dit teen 'n identies gekleurde agtergrond en tekstuur geplaas word. Hierdie siening is gebaseer op die reeds genoemde Taoïstiese beginsel van Yin en Yan, "the principle of polarity, which is not to be confused with the ideas of opposition or conflict" (Watts, 1975:29).

Dit gaan met ander woorde hier om 'n beginsel van relatiwiteit; die verstand kan net 'n idee vorm van 'beweging' aan die hand van 'nie-beweging', of van 'lewe' aan die hand van 'dood'. Alles wat die verstand uitsonder of raakvat, gebeur slegs in verhouding tot die teenstelling daarvan. Daarom sê Watts (1975:83) "... all things are without 'self nature' (svabhava) or independent reality since they exist only in relation to other things". Maar mér as dit: hoewel daar sonder 'lewe' nie 'dood' is nie, is elke ding se eie teenpool altyd reeds inherent in homself teenwoordig; in elke oomblik van 'lewe' is 'dood' reeds teenwoordig, en andersom. Hoewel lewe en dood teenstellende prosesse skyn te wees wat mekaar negeer, is hulle onlosmaaklik aan mekaar verbind as twee pole van één en dieselfde verskynsel. Breytenbach se gewoonte om twee woorde met teenstellende 
betekenis saam te smelt verbeeld sodoende die inherente samesyn van skynbare teenstrydighede. Die bundeltitel Lewendood impliseer byvoorbeeld nie net dat lewe en dood as twee kante van een en dieselfde verskynsel gesien word nie, maar dat die een inherent en altyd reeds in die ander teenwoordig is. So word die inherente samesyn van oënskynlike teenstellings deurgaans besing in sy poësie: "daar is in elke man 'n vrou / dit wat pyn soos 'n blom vol geur is" (Breytenbach, 1985:47).

Hierdie relatiwiteit waardeur die heelal in balans gehou word is inherent harmonies en kreatief, omdat daar geen destruktiewe konflik kan wees tussen pole wat van mekaar afhanklik is vir hul eie voortbestaan nie: "Conflict is always comparatively superficial, for there can be no ultimate conflict when the pairs of opposites are mutually interdependent" (Watts, 1957:194).

Gevolglik word die begrensde, afgebakende aard van dinge deurbreek: 'ek' en 'jy' is nie net twee pole van een en dieselfde verskynsel nie, maar 'ek' is inherent ook teenwoordig in 'jou', en andersom. Vandaar stellings soos "when Lee drinks the wine, Chang gets drunk" (Abe, 1985:3). Die wedersydse afhanklikheid van Yin en Yang impliseer dat die heelal in sy geheel gebaseer is op wedersydse interpenetrasie en interafhanklikheid, met ander woorde dat die hele kosmos implisiet teenwoordig is in elke aspek daarvan (Watts, 1975:35). Daarom kan die Zennis sê "every single thing is itself, a single, limited thing, and all other things, and all things" (Blyth, 1978:92). Vergelyk ook Breyten (1983b:36):

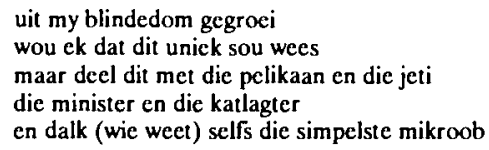

Ook Breytenbach se skilderkuns is sprekend van hierdie relatiwiteitsbeginsel, en beweer hy (1991:76): "Every portrait - landscape or poem or other depiction - is a selfportrait". Dit spreek duidelik uit sy skilderye waar sy eie gesig telkens herkenbaar is, en ook in sy poësie waar die fokus op die 'ek' baie opvallend is en op die oog af nie strook met die sosiale en politiese betrokkenheid waarvoor hy andersins bekend is nie. Dit behoort egter uit die voorafgaande duidelik te wees dat dit juis nie gaan oor die individu Breyten Breytenbach nie, maar eerder dat hy homself, gelyktydig en tesame met elke ander bestaande wese, as vasal van die ganse wêreld en mensdom ervaar. (Kyk verder Breytenbach, 1987:185.)

Hierdie konsep van nie-dualiteit, van wedersydse afhanklikheid tussen kontrasterende pole gee direk aanleiding tot 'n essensiële kernkonsep in die Zen-Boeddhisme naamlik die Groot Niet, soms genoem die Al (Sunyata, 'leegheid'). Die gewaarwording of bewussyn van Sunyata is die Satori wat die Soto Zen-Boeddhis uitleef in sy gewone, alledaagse lewe, en kan soos volg omskryf word:

Heaven and earth are one finger, all things are one horse

(Chuang Teu, soos aangehaal deur Breytenbach in All one horse, 1990a:9).

\subsection{Die Groot Niet}

Dit is verarmend en beperkend om Zen te omskryf as ' $n$ siening waarvolgens alles in die wêreld soos 'n legkaart by mekaar inpas om een geheel te vorm. Want véél meer as dit is die werklike implikasie dat alles, elke ding wat 'is', terselftertyd ook die ganse heelal bevat 
en omvat. "By interpenetration, every single thing is itself, a single limited thing, and all other things, and all things" (Blyth, 1978:92).

Die sodanige opheffing van dualiteit impliseer dus 'n toestand van nie-dualiteit, wat egter weer 'n toestand van dualiteit suggereer (naamlik dualiteit teenoor nie-dualiteit). Hierdie toestand moet getransendeer word; 'n dubbele of tweede negasie van die dualiteit wat byvoorbeeld deur 'lewe' en 'nie-lewe' teweeggebring is, moet gemaak word, voordat ervaring van die Groot Niet (Sunyata) moontlik is. Omdat hierdie kernbeginsel van Zen so noodsaaklik is vir ' $n$ begrip van die Breytenbach-oeuvre, word die volgende aanhaling van Abe (1985:127) hier in sy geheel gegee:

\begin{abstract}
This dialectical structure of Sunyata may be logically explained as follows: since Sunyata is realized not only by negating the 'eternalist' view, which negates the former, it is not based on a mere negation but on a negation of the negation. This double negation is not a relative negation but an absolute negation. And an absolute negation is nothing but an absolute affirmation, logically speaking, the negation of the negation is affirmation. Yet, it is not a mere and immediate affirmation. It is an affirmation which is realized only through double negation, i.e. absolute negation. Thus we may say that absolute negation is absolute affirmation and absolute affirmation is absolute negation. This paradoxical statement well expresses the dialectical and dynamic structure of Sunyata in which Emptiness is Fullness and Fullness is Emptiness.
\end{abstract}

Die leerstelling van non-attachment wat hieruit voortspruit, sluit direk aan by die ZenBoeddhistiese siening van selfbewussyn, en die manier waarop dit neerslag vind in Breytenbach se werk. Die leegheid wat deur die transendering van dualiteit bereik word, moet nie nagestreef of aangekleef word nie. Ware non-attachment impliseer dat dualiteit sowel as nie-dualiteit getransendeer word: dán alleenlik word die Groot Niet betree. Hierdie Absolute Leegheid ( "Die stilte van die diepste insig, anderkant woorde en begrippe") is nie 'n konsep wat intellektueel begryp kan word nie; "dit is by wyse van spreke dít wat nie gesê kan word / omdat dit te eie is aan die tong" (Breytenbach, 1983b:162). As dinamiese proses kan dit net in die huidige oomblik, eksperimenteel en eksistensieel beleef word. Dit is dan ook in hierdie sin wat dit aansluit by die skryfproses wat " 'n poging (is) om die niet te struktureer, dit wil sê lyne te gooi oor die oneindigheid" (Breytenbach, 1990 b:135).

The Buddhist idea of Emptiness can be properly realized not conceptually, but only holistically, subjectively, or existentially through the realization and subsequent breakthrough of one's own existence as a self-contradictory oneness of being and non-being ... (Abe, 1985:129).

Die grens tussen dualiteit en nie-dualiteit word dus nie alleen opgehef nie, maar alles bestaan ook in 'n omruilbare verhouding tot mekaar, waardeur 'n toestand van verbyheid, anderkantheid beleef word. Dit is waaroor die "Hart Soetra" voor in ("Yk") gaan, waar die omruilbare verhouding van leegheid en vorm in die Groot Niet besing word. As inleiding tot die bundel het dit direk betrekking op die aard van die teks: waar daar konvensioneel 'n verband bestaan tussen vorm en inhoud, word dit hier opgehef en verbeeld die verbrokkelde struktuur en talryke beelde van verganklikheid en onbepaalbaarheid 'die groot betowering' van absolute wysheid (Prajnaparamita).

Dit is dus duidelik dat die Zen-Boeddhistiese 'leegheid' nie as nihilisties beskou kan word nie, want dit is nie 'leegheid' in teenstelling met 'volheid' nie, dit is 'n leegheid wat die teenstelling 'leegheid-volheid' transendeer en albei pole insluit. Dit is 'n leegheid wat werklik leeg of vormloos is omdat dit bevry is van sowel 'vorm' en 'vormloosheid'. Sunyata "transcends every possible duality including that of being and non-being, (it ...) transcends and embraces both emptiness and fullness" (Abe, 1985:126). 
Om die Groot Niet van Zen as nihilisties te beskou is om daarvan 'n konsep te maak, en is dus om weer eens te trap in die slagyster van die intellek, van die 'rasionele' denke waardeur alles gekategoriseer word. Want om iets as nihilisties te klassifiseer impliseer die bestaan van 'n antoniem: vir die Westerling is iets nihilisties wanneer dit nie betekenisvol is nie. Dit is dus hierdie kategorisering wat deurbreek moet word. "Even the foothold of Sunyata must be kicked off (Suzuki, 1957:54).

Ervaring van die Groot Niet word Satori genoem, en is volgens Soto-Zen één met Satori.

\title{
3.6 Zazen as Satori
}

\author{
Mount Lu in misty rain; the River Che at high tide. \\ When I had not been there, no rest from the pain of longing! \\ I went there and returned ... It was nothing special: \\ Mount Lu in misty rain; the River Che at high tide
}

(Watts, 1957:146).

Hierdie Sjinese gediggie word dikwels gebruik om Satori oftewel betreding tot die Groot Niet te beskryf, en is ' $n$ aanduiding van die probleem om iets wat duidelik net eksistensieel ervaar kan word, in rasionele, intellektuele terme te wil beskryf. Die beste manier om te werk te gaan is moontlik om enkele wanopvattings oor Satori uit die weg te ruim.

Die opvatting van Satori as 'oomblik van ontwaking' of van 'waarheid' is byvoorbeeld misleidend. Satori se 'oomblik van waarheid' impliseer eerder die besef dat die waarheid juis nié geken kan word nie. Getrou aan die beginsel van nie-dualiteit kan Satori nie gestalte gee aan 'n absolute, bepaalde, onveranderlike 'waarheid' nie, want dit impliseer onmiddellik die teenwoordigheid van 'n teenpool, in hierdie geval dié van leuen; 'onwaarheid'. In End Papers (1983 d:100) sê Breyten: "There is in fact no Truth. We are too fragile and volatile for that; we work with too many uncertainties. There is rather the continual shaping of something resembling, poorly, provisionally 'truth'."

Satori transendeer met ander woorde die dualiteit van 'waarheid - onwaarheid' ; 'ontwaking - nie ontwaking' en kan hoegenaamd nie intellektueel geformuleer of gedefinieer word nie, omdat dit dan weer eens net 'n konsep sal wees, wat altyd onmiddellik 'n teenpool impliseer.

Volgens die Rinzai-skool word Satori deur die gebruik van 'n koan bereik, en is dit 'n skielike gebeurtenis wat soms met 'n weerligstraal vergelyk word. Daarteenoor sien die Soto-skool Satori as 'n geleidelike proses, wat ten beste deur middel van Zazen (sitmeditasie) in werking gestel word. Waar Satori tradisioneel beskryf word as die oomblik wanneer die Ontwaakte persoon ervaar dat elke wese die sogenaamde 'Boeddha-aard' soos 'n saadjie in homself dra, dring Dogen (stigter van Soto-Zen in Japan) daarop aan dat alles reeds die Boeddha-aard is. "Dogen (...) rejects any notion that the Buddha-nature is a seed. It is already the flower" (Williams, 1989:115). Die bewussyn (verstand of mind) is soos 'n spieël wat tydens meditasie in staat is om die 'so-heid' (suchness) van die wêreld te registreer, maar dit nie vas te pen nie. (Vergelyk in hierdie verband die bundeltitel Soos die So.) Dit is hierdie bewuswees van nie-bewuswees wat die "mind of Buddha", die sogenaamde Boeddha-aard genoem word.

Die Groot Niet wat deur Satori betree word, is volgens Versfeld (1991:165) 'n toestand 
waarin ware kreatiwiteit kan plaasvind, maar moet hoegenaamd nie gesien word as 'n soort panteïsme waarin die individu verlore gaan soos 'n druppel water in die see nie. "The Buddhist Nirvana is not annihilation, but the ascent out of the dark waters, where desire has been washed away. Bliss is not getting what we want, but being what we are" (Versfeld, 1991:165). Hierdie siening belig die verhouding tussen Breytenbach se skilder-en woordkuns. In Hart-lam (1991:73) skryf hy: "Maybe you never create anything; maybe you can only help uncover the deadened feeling of being alive by peeling the eye ...". Hy praat hier van die kreatiewe skryf- of skilderproses, maar dit moet gesien word binne die Boeddhistiese konteks waarvolgens jy word wat jy is. Deur jou gedig of kunswerk skep jy nie 'n self nie, jy ontbloot net dit wat alreeds daar is, en dít is altyd proses.

\subsubsection{Die eksistensiële ervaring van Satori}

Net soos die kreatiewe skeppingsproses kan Satori alleenlik eksistensieel ervaar word, en ontsnap dit aan intellektuele beskrywing of waarneming. "No description by analogy is possible of this state where all relations have ceased" (Seng-t'san aangehaal deur Breytenbach, 1987:27). Voorts is die Breytenbachgedig of kunswerk altyd in proses (Sienaert, 1991:23-33); Satori is nie 'n toestand nie. "Enlightment is not a state; it is an activity" (Blyth, 1978:104). Hierdie aspek is belangrik omdat die voortdurende transformasie, metamorfose en kreatiewe aksie inherent aan Zen, sentraal staan in die Breytenbach-oeuvre. Dit is die "joyful despair of metamorphosis" (Breytenbach, 1991:75) van die kreatiewe proses. In sy skryf- sowel as in sy skilderkuns word die klem geplaas op die skeppingsproses as transformasieproses, en is die eindproduk van sekondêre belang. Ontwaking of Satori word gekoppel aan wording, en dit is in hierdie verband dat ' $n$ Breytenbachgedig met 'n oomblik van Satori vergelyk kan word (vergelyk Botha, 1988:18). Satori as 'wording' is altyd 'n geval van transformasie, en vind 'n parallel in die kreatiewe skryfproses: "Kommunikasie is onvermydelik transformasie, metamorfose" (Breytenbach, 1987:160). 'n Duidelike voorbeeld van die gedig as oomblik van wording en transformasie is die inleidingsgedig in (" $Y k$ ") (1983b:3), waar die kommunikasieproses tussen skrywer en leser in werking gestel word:

\footnotetext{
uit die kosmiese geraas binne en buitc breek die watergladde hingste silwer soos soliede vloei en vaslê van newel om uit die inbloei van droomstroom te haal die kreet klankeloos dic lag dicp uit dic keel tc skaat
}

Die skryfproses as 'omgang' tussen die aanvanklik afsonderlike pole van skrywer en leser word treffend verbeeld met die saamtrek van inherent teenstellende woorde (soos "soliede vloei", "vaslê van newel" en "inbloei") waardeur oënskynlike teenstellings tot eenheid geïntegreer en dus getransformeer word. Die transendering van dualiteit vind dus 'n analogie in die ophef van die 'ek'-en-'ander'-dualiteit wat deur die skryf van die gedig in werking gestel word: die "cunnilingus van die vuurkoue hart" (versreël 9) breek letterlik uit tot 'n oomblik van Satori, wat dikwels gekenmerk word deur die klankelose lag van versreël 14. Dit is juis binne die Zen-tradisie dat die bekende "laggende Boeddha" die verwantskap tussen lag en Ontwaking aantoon. Die verband tussen Satori en die erotiese wat so opvallend is in hierdie gedig en in die Breytenbach-oeuvre oor die algemeen, word gewoonlik met die Tantriese Boeddhisme geassosieer, maar vind nietemin ook aansluiting by die Zen se oomblik van Satori (kyk verder Breytenbach, 1987:87). 
Breytenbach se konstante gebruik van beelde van metamorfose (byvoorbeeld waterverwante beelde, die verkleurmannetjie, die vlinder, en so meer) onderskraag die beginsel van skryf as proses van transformasie, en daarom Satori. In Boek (1987:78-79) verduidelik Breytenbach dat Satori 'n houding of postuur tot gevolg het waardeur inspirasie ontvang en gelei word, en dus in direkte verband met die kreatiewe proses staan. Satori en kreatiwiteit verkeer, soos die spreekwoordelike hoender en die eier, in konstante interaksie en metamorfose.

Satori as transformerende proses impliseer egter onmiddellik ook die teenwoordigheid en integrasie van stilte of roerloosheid as teenpool, wat Suzuki (1957:35-36) op digterlike wyse beskryf as die "silence of thunder obtained in the midst of the flash and uproar of opposing electric currents". Dit word ook beskryf as die oog van die orkaan, 'n nukleus van absolute gesentreerde bewegingloosheid waarsonder die geweldige transformerende krag van die orkaan nie moontlik sou wees nie. Vandaar die motief van die "ongedansde dans" wat Breytenbach as subtitel vir sy tronkbundels gebruik, (kyk verder in hierdie verband Herrigel, 1953:89). Hierdie beeld van getransendeerde dualiteit is 'n direkte toepassing van Satori op die teks.

Hoewel die Zennis veronderstel is om sy ervaring van die Groot Niet deur middel van absolute aandagtigheid of konsentrasie (mindfulness) elke oomblik van sy daaglikse lewe ("te midde van die orkaan") uit te leef, is dit deur gesentreerde, gedissiplineerde roerloosheid van Zazen dat hy Satori eksistensieel ervaar en in sy wese as geheel kan integreer:

\footnotetext{
Jou ganse wese is 'n long. Met die uitasem gaan jy oop, word geledig, jou hele innerlike vloei na buite en vergaan, word deel van die totaliteit, die niet; met die inasem kom alles wat om en buite jou is na binne en word deel van jou. Dit is die oplossing (oplos-sing): daar is twee bewegings, 'n dualiteit, 'n kom en gaan - maar albei is geïntegreer in die kom-en-die-gaan (die $\mathrm{Al}$ ) en so is daar beweging sonder dat daar beweging is, is daar stilwees sonder ophou. Alles om jou is ' $n$ long, en jy word in- en uilgeadem (Breytenbach, 1987:80).
}

\subsubsection{Die meditasieproses}

Zazen, Breytenbach se "kruissit bid" (1987:39) is die Zen-term vir meditasie, en is die kerngegewe van die Soto-skool. Zazen vestig al die aandag op die asemhalingmeganisme, soos bogaande aanhaling duidelik illustreer. Ná 'n lang tydperk van gedissiplineerde stilsit bereik die mediteerder uiteindelik 'n vlak van versinking waarin alle teenstellings opgehef is, en waar konsepte van tyd en ruimte getransendeer is, met die klem op die onmiddellikheid van ervaring.

Begrip van hierdie meditasieproses is van primêre belang vir 'n studie van die Breytenbachoeuvre omdat al bogenoemde eienskappe van Zazen 'n spesifieke manier van 'sien' impliseer wat kenmerkend is van sy werk. Breytenbach (1987:74) beskryf dit as "suiwer sien, nie om na die werklikheid te kyk nie, maar as die werklikheid". Die sogenaamde Zen beginner's mind vereis dat die mediteerder alles in die wonder van die oomblik beleef, asof die wêreld vir die eerste keer waargeneem word. Dié Zennistiese siening hou eerstens verband met die manier waarop linière of chronologiese tydsverband opgehef word, en tweedens met die waarneming van 'so-heid' (suchness).

Deur middel van Zazen word 'tyd' as konsep getransendeer, dit is "a liberation from time. For if we open our eyes and see clearly, it becomes obvious that there is no other time than this instant, and that the past and the future are abstractions without any concrete reality" 
(Watts, 1957:218). Verlede tyd en toekomstige tyd is met ander woorde net die illusie wat volg op ons konseptuele, diskursiewe manier van dink; die ewigheid lê in die wonder van die huidige oomblik. Interessant genoeg sluit Zen hier volgens sommige skrywers aan by die geskrifte van die Katolieke Heilige Augustinus, waarvolgens 'tyd' dieselfde as 'wees' is, "which is beyond both continuity and discontinuity" (Abe, 1985:52. Kyk ook verder in hier die verband Versfeld, 1990:60-61 en 87-99). Die 'wees' van die Boeddha, (Zazen word beoefen juis om te ervaar dat alles en almal reeds deel het aan hierdie wesenstoestand Suzuki, 1957:34) ), word gelykgestel aan tyd: "... time is being and being is time. Becoming as 'impermanence - Buddha nature' involves the paradoxical unity of time and eternity at each and every moment" (Abe, 1985:55). Liniêre opvolging van oomblikke in tyd is dus slegs ' $n$ konsep en daarom ' $n$ illusie: elke oomblik is net eenvoudig wat dit is, en moet in sy 'so-heid' beleef word. Daarom kan Breytenbach (1983c:72) sê: "en die gedig / is die betekenis van die gedig"; die betekenis van die teks is net dít wat op die betrokke lees- of skryfmoment ervaar word. Zen-meesters gebruik graag die seisoene as voorbeeld van 'soheid': Winter is winter en moet as sodanig beleef word, winter is nie die gevolg van herfs, of die oorsaak van lente nie. Soos elke oomblik, elke gedagte, elke ervaring, " (they) follow one another without being linked together. Each one is absolutely tranquil" (Ku-tsun-hsü Yü-lu, soos vertaal in Watts, 1957:143).

Die vermoë om alles in die 'so-heid' van die oomblik waar te neem hou direk verband met bogaande beskrywing van tyd. Alles is net eenvoudig soos wat dit is, sonder dat enige konsepte of waardebepalings te staan kom tussen subjek en objek. Die 'sien' van Zazen impliseer juis dat die ruimte en tyd tussen warnemer en dit-wat-hy-waarneem opgehef word. "Dit is nie mediteer soos die woord gewoonlik verstaan word nie - wel 'n kontemplasie en meelewe sonder aanklewing, sonder vaste waarnemingspunt wat 'n opinie of 'n stellingname kan impliseer" (Breytenbach, 1987:80). Tathata is die term wat hiervoor gebruik word en verwys na die wêreld in sy konkreetheid en aktualiteit, "unscreened and undivided by the symbols and definitions of thought" (Watts, 1957:88).

Dit is in hierdie konteks dat die Zen-beskrywing van die verstand (mind) as spieël verstaan moet word (en die ingewyde Breytenbach-leser sal dadelik 'n verband lê met die spieël wat as motief so sterk fungeer in sy werk). Daar word tydens Zazen nie weggedoen met gedagtes nie, bewussyn word nie opgehef nie, maar gedagtes word ervaar as beelde wat voor 'n spieël verbyskuif sonder om daaraan vas te klou. "The perfect man employs his mind as a mirror. It grasps nothing; it refuses nothing. It receives, but does not keep" (Chuang-tzu, soos aangehaal deur Watts, 1957:39). Kyk verder in hierdie verband ook Williams, 1989:195-196).

In verband met die Breytenbach-oeuvre moet onthou word dat die Soto-skool (in teenstelling met ander vorme van Boeddhisme) Zazen gelykstel aan Satori. Zazen is dus nie die middel waardeur die doel bereik word nie: die meditasieproses is reeds die doel. Breytenbach (1987:80) beklemtoon dit self. Die sleutel tot hierdie siening lê in Dogen se leerstelling dat die mens alreeds die Boeddha-aard is, en dit dus nie hoef na te streef nie: "To think that practice and enlightment (Satori) are not identical is a non-Buddhist view ... Therefore, even though you are instructed to practice, do not think that there is any attainment outside of practice itself, because practice must be considered to point directly to intrinsic realization" (my kursivering, M.S., soos vertaal in Williams, 1989:115).

Die gedig as oomblik van Satori impliseer dus 'n duidelike verband tussen Zazen en die kreatiewe proses. Byna al die Zen-bronne wat geraadpleeg is maak hiervan melding. Die 
rede hiervoor is dat enige menslike aktiwiteit 'n vorm van Zazen kan wees, afhangende van die persoon se houding en vermoë tot ware 'aandagtigheid' (mindfulness) (Watts, 1957:218). Vir Breytenbach is die ideale kreatiewe proses 'n vorm van meditasie, waardeur die konvensionele ervaring van liniêre tyd deurbreek word en waartydens die gedig of skildery as instrument die onsêbare verwoord en uitbeeld. "Vir die digter is dit - in savante onkunde - die eie-maak, die besit neem van dit wat nie uitgedruk kan word nie" (Breytenbach, 1987:68). In hierdie lig moet Breytenbach (1987:78-79) se stelling dat Zen en die beoefening van Zazen 'n kwessie van die "korrekte houding" is, gesien word. Sodoende kan inspirasie oftewel intuïtiewe, meditatiewe kennis ontvang word en tot uiting kom in die kunswerk of gedig, omdat "korrekte postuur ... gedig is".

Dit is noodsaaklik om te onthou dat die Satori van Zazen opgesluit lê in die proses self, net soos die eindproduk in Zen-kuns ondergeskik is aan die uitvoering daarvan (Watts, 1957:216). "Die gedig" sê Breyten (1987:68) "is die gebeur". 'n Breytenbach-gedig, as 'Satori in die kleine', beteken dat Ontwaking ervaar word deur die gedig-as-proses, tydens die skryf of die werklik intuïtiewe meditatiewe lees daarvan. Proses impliseer transformasie en metamorfose; altyd primêre motiewe in sy werk.

\subsection{Die 'self': die klem op konstante verandering}

There is no I, just a series of temporary jottings, a brief bundling of being which will delineate as if along a dotted line the passage of an I (eyc), an ancestor, a mask (Breytenbach, 1991:77).

Soos reeds verduidelik, is die Westerse ego of self 'n konsep, die resultaat van ons konseptuele, diskursiewe manier van dink. Die Westerse subjek-objek-dichotomie word toegeskryf aan ons antropomorfiese siening van die wêreld waar alles deur middel van die verstand en sintuie 'geken' word: die wêreld om jou is letterlik wat jy daarvan maak, en hierdie siening reflekteer ons (foutiewe) aanname dat die ego 'n identifiseerbare, permanente entiteit is.

Omdat ons die ego as permanente entiteit ervaar, verkry al ons projeksies (vrees, aggressie ens.) ook soliditeit. Hierdie soliede subjek wat die Westerling daarstel as bron van alle ervaring is egter vir die Zennis 'n illusie, en is die hoofoorsaak van alle ellende, omdat dit die onvermydelik voortvloeiende, verbygaande aard van alle dinge nie kan akkommodeer nie. In Zen val die klem dus op kontinuïteit en nie op identiteit nie:

The name you will see under this document is Breyten Breytenbach. That is my name. It's not the only one; after all, what is a name? I used to be called Dick; sometimes I was called Antoine; some knew me as Hervé; others as Jan Blom; then I was the Professor; later I was Mr. Bird: all these different names with different meanings being the labels attached to different people. Becausc, Mr. Investigator, if there is one thing that has become amply clear to me over the years, it is exactly that there is no one person that can be named and in the process of naming be fixed for all eternity (Breytenbach, 1984b:13).

Volgens die Boeddha is "the cause of suffering (...) the obtrusion and magnification of the ego" (Versfeld, 1991:160). Verlossing of vryheid is om eksistensieel te besef dat die permanensie van die fenomonale wêreld net skyn is, en meditatief getransendeer kan word. Die raaiselagtige aanhaling in (" $Y k^{\prime \prime}$ ), van Gary Trudeau (1983b:5) verkry binne hierdie lig betekenis: "I've been trying for some time now to develop a life-style that doesn't require my presence." 
Die ego as "a series of temporary jottings" word weerspieël in die Zen-siening van tyd, en in die manier waarop dit neerslag vind in die Breytenbachteks. Met Zazen word (byvoorbeeld deur middel van konsentrasie op asemhaling) ego- of selfbewussyn tydelik opgehef, wat die onmiddellike bevryding van 'n liniêre konsep van tyd tot gevolg het. Sodoende word elke oomblik in sy afsonderlikheid en 'so-heid' beleef. Alleenlik op dié manier word tyd as maatstaf van sterflikheid getransendeer, en beleef die Zennis sy Satori as integrasie met die tydlose, ewige Niet. Transendering van ego-identiteit loop dus parallel met transendering van liniêre, historiese ervaring/waarneming van tyd. In hierdie konteks impliseer 'transendering' egter nie die oorgang na Iets Anders nie, maar wel die bevrydende aanvaarding van die paradoksale verstrengeling van tyd en 'ewigheid' hier en nou. Samsara (die wêreld wat deur die verstand en die sintuie 'geken' word) is nirvana.

In "Ek is hier, parodie", die laaste gedig in die tronkbundelreeks, word die transendering van tyd, wat met Satori as kreatiewe proses gepaard gaan, duidelik (soos dikwels elders in die oeuvre) uitgespel:

\author{
Daar is tóg geen moeite op die Groot Weg nie. \\ Dis hier waar bespiegelinge wit op wit stapelskryf \\ en kennis kan dit nie peil nie. Lecg, ligryk \\ soos 'n uitgebrande brand: verder as alle tale - \\ vir dit is daar geen verlede, geen hede, geen toetrede nie
}

(1983b:162).

\title{
3.7.1 Die ego en die manipulasie van tydaanwending
}

Die manier waarop tyd in die poësie getransendeer word vind ook duidelik neerslag in die manier waarop Breytenbach die konvensionele aanduidings van tyd manipuleer. (Kyk ook Breytenbach, 1983b:28-29.) Liniêre tyd word deurbreek deur onder meer die gebruik van verwarrende sintaksis en teenstrydige tydverwysings soos "want terwyl ek mettertyd gaan skrywe / en selfs wanneer jy noú lees nou" (1983b:3) of "alles wat was en alles se is en alles sal wees / is my gebied / - ook alles terselfdertyd en te vergeet - " (1984a:161). Maar dit is ook in die gedig as ewig wordende proses wat dit gestalte kry, hier verbeeld in voëlvlug: "elke woord uitgebring vir eendag se tuiste / is 'n swerwende voël wat die lug blou krabbel / van wat op die hart weeg" (1983b:148).

Inherent aan hierdie siening van tyd is die beginsel van transformasie. Hoewel alles 'is' soos wat dit is, is alles terselftertyd ook in ' $n$ konstante toestand van metamorfose. Daarom geld dieselfde ook vir die ego: "... each person is a succession of fleeting selves, with the illusion of continuance and permanence" (Blyth, 1978:111), of in die woorde van Breytenbach (1987:112) "ek is slegs die tydelike som van my indrukke ... wat vervaag, wat geïnterpreteer, wat uitgevind word ... wat vernuwe word: ek is 'n reeks gebeurtenisse".

Boeddhisme beskou dus die ego of self as 'n toestand van konstante verandering waar geen aanspraak op permanensie gemaak word nie. Sentraal hieraan is die beginsel van paticcasamuppada (dependent arising), (kyk Kalupahana, 1992:53-59 vir 'n helder uiteensetting hiervan), waarvolgens niks, ook nie die self, onafhanklike en eie bestaansreg het nie. Alle lyding kom tot 'n einde wanneer 'n mens hierdie beginsel eksistensieel ervaar (soos byvoorbeeld tydens Zazen), en nie net intellektueel begryp nie. Die Zen-Boeddhis streef hierdie gewaarwording nie doelbewus na nie, want dit sou dan nog steeds 'ek' (subjek) wees wat 'n ideaal (objek) nastreef. Enige strewe impliseer dat daar ook gekleef word aan die konsep van 'n ego, en weerspieël 'n toestand van vervreemding. Purusa of die 
Boeddha-aard is altyd reeds teenwoordig; dit moet net 'n kans gegun word om te wés. Die Westerse soeke na identiteit en strewe tot selfverwesenliking is gebaseer op ' $n$ illusie. "What we are is something to be revealed and not made" (Versfeld, 1991:161).

\subsubsection{Die 'self en die 'ander': geen permanente entiteite}

Hiérdie siening van die 'self' impliseer egter dat die 'ander' ook nie as permanente entiteit beskou kan word nie. Daar is geen onafskeidbare unieke wese anders as ek self nie; alle wesens is verenig deur hul gemeenskaplike Boeddha-aard. Vir die Zennis is "the other's reality as fully real as his own", en sal hy die ander geen kwaad aandoen nie, want hy is die ander. Om Blyth (1978:xvii) aan te haal:

The Awakened Mind, for whom the other's reality is fully as real as his own, is incapable of harming the other, for there is no 'other': 1 am neither 1 nor other.

Die inherente samesyn van alle dinge as deel van één en dieselfde proses, skyn op die oog af in direkte teenstelling te staan met die skeppingsdaad van die digter of kunstenaar, wat sy werk immers baseer op die oneindige differensiasie en uniekheid van dinge in die samsariese wêreld. Die antwoord hierop lê in die feit dat daar eenheid kan wees in en deur differensiasie.

Om hierdie stelling te verduidelik kan die Westerse, Bybelse tradisie as metafoor gebruik word (kyk ook Versfeld, 1991:165-166). In Genesis skep 'n unieke God wesens na sy beeld wat elkeen, as beeld, uniek is. Om dus waarlik na die beeld van God geskape te wees, impliseer uniekheid van die skepsel, maar paradoksaal ook gemeensaamheid met alle ander skepsels wat na dieselfde Beeld geskape is. Dit is dan ook die implikasie van die Boeddhistiese eenheidsbeginsel:

You never enjoy the world aright till the sea itself floweth in your veins, till you are clothed with the heavens, and crowned with the stars: and perceive yourself to be the sole heir of the whole world, and more than so, because men are in it who are everyone sole heirs as wcll as you (Traherne soos aangehaal deur Versfeld, 1991:166).

Volgens die beginsel van dependent arising word die "uniformity of phenomena (dhammaniyama) as well as their interdependence (idappaccayata)" (Kalupahana, 1992:55) vooropgestel. Om hierdie eenvormigheid in teks of kunswerk te verbeeld impliseer 'n geweldige paradoks, omdat die skryf van 'n gedig immers differensiasie van woorde vereis, net soos wat die skilder van 'n toneel differensiasie van objekte verg. Soos hierbo verduidelik, word dié paradoks alleenlik getransendeer deur die beginsel van eenheid in en deur differensiasie. Die Zen-Boeddhistiese ervaring dat alles 'een' is en wat by Breytenbach paradoksaal 'n voorvereiste is vir die uniekheid van die kunswerk, word bewerkstellig deur "die oplossing van self en die totale respek vir die Ander" (Versfeld, 1991:30).

Die uitreik na 'n 'ander' is dus déél van die Zen-selfbewussyn, deel van die beginsel van dependent arising, vandaar ook liefde of medelye (compassion) wat die hoofgegewe van die Boeddhisme is. Dit impliseer dat die kunstenaar of digter wie se identiteit in sy werk uitdrukking probeer vind, altyd ook die identiteit van die 'ander' onwillekeurig sal betrek. By Breytenbach vind dit op ten minste twee maniere neerslag. 
Eerstens vorm die leser of kyker by Breytenbach altyd 'n integrale deel van die betrokke kunswerk: hy of sy is altyd die noodsaaklike teenpool vir die proses waardeur die werk gestalte aanneem: Soos Blyth (1978:288-289) dit stel, "... when (the Zen Master) Rinzai cries: 'Speak!' he means clearly that we must not merely express what impresses us but must express this impression to somebody, somebody real or imagined." Die geliefde wat deurgaans in sy poësie aangespreek en betrek word is dus juis hierdie "somebody real or imagined", die 'ander' waarsonder Satori (oftewel die kreatiewe proses) nie moontlik is nie.

\subsubsection{Die interafhanklikheid tussen kunstenaar en kunswerk}

In die tronkbundels word die fisieke afwesigheid van 'n 'ander' treffend besweer deur middel van die skryfproses: "kyk ek kom weer / en intussen / oor hierdie papier wat sonder einders is / skryf ek blind skryf ek stom na jou toe" (Breytenbach, 1976:10). Veral in ("Yk") word die spel tussen digter en leser, reeds teenwoordig in die aanvangsgedig ("Omgang"), deurgaans volgehou en verleen dit 'n soort alchemistiese energie aan die hele bundel deur die bevrydende oomblikke van 'so-heid' wat deur sowel digter as leser ervaar word; "om dit wat is tog / stilstaande neer te dig" (1983b:30, my kursivering). In Breyten se skilderkuns is dit duidelik in werke soos "Femme" (1968), waar die uitstrek na buite van die figuur se interne organe, of in "Confession véridique d'un terroriste albinos" (1984) waar die uitreik van twaalf hande na mekaar dieselfde beginsel visueel verbeeld.

Tweedens impliseer die beginsel van interafhanklikheid wat so sentraal staan binne die Breytenbach-oeuvre 'n bepaalde verhouding tussen skepper en skepsel, tussen digter en teks, tussen leser en teks, tussen kunstenaar en kunswerk. Die teks of skildery word beeld (of spieël) van die digter/kunstenaar, en Breytenbach bevestig dit onomwonde in gesprek met Jacques Leenhardt (aangehaal in die katalogus van 'n retrospektiewe Breytenbachuitstalling in Montreuil, 1987:5):

\footnotetext{
"(...) l'image montrerait Breytenbach, toujours lui, sous les traits d'une automobile ou d'un quelconque de ces objets qui viendrait à sa fantaisie, une chaussure peut-être, ou une tête de cheval, bref, une forme qui cristalliserait ses sensations, ses sentiments, cettc perception de soi qui déclenche l'écriture ou la peinture au moment où il se saisit. Cette fantaisie (...) que je tiens de Breytenbach lui-même, manifeste bien qu'à ses yeux l'identité même de l'artiste prend sur la toile autant de formes que son imagination peut en produirc. L'image montre qu' autant de fois je fais l'effort de me saisir dans mon essentialité, autant de fois je suis autre. Ce que l'image montre vient indéfiniment à la rencontre de la phrase du poete: "Je est un autre".
}

(die beeld /skildery toon Breytenbach, altyd hy, onder die aanskyn van 'n motor of enige objek wat sy verbeelding aangryp, moontlik 'n skoen, of 'n perdekop, in kort, ' $n$ vorm wat sy gewaarwordings, sy gevoelens laat uitkristalliseer, dié (soort) ervaring van self(bewussyn) wat die skryf- of skilderaksie in werking stel die oomblik wat dit plaasvind. Hierdie fantasie (..) wat deur Breytenbach self aan my vertel is, toon duidelik dat in sy oë die kunstenaar se identiteit op die doek soveel vorms aanneem as wat sy verbeelding kan produsecr. Wat die beeld toon, sluit sonder voorbehoud aan by die woorde van die digter: "Ek is ' $n$ ander" (M.S)).

\subsubsection{Die kunstenaar se 'selfportret' kan enige vorm aanneem}

Só word die skildery van 'n skoen op 'n tafel met 'n papegaaikop daarnaas "selfportret" genoem, of eweneens dié van 'n perdekop: elk telkens 'n vergestalting van die kunstenaar se Zen-Boeddhistiese deurbreking van die subjek-objekpolariteit. Want tydens die kreatiewe proses, en ook nét momenteel, word die subjek-objekdichotomie net soos in die 
geval van Satori opgehef/getransendeer, en kan die kunstenaar se 'identiteit' of selfportret enige vorm op die doek aanneem. Die 'ek' wat só op die doek vergestalt word, verbeeld dus die veronderstelling dat 'ek', sodra ek probeer om myself in my volle essensie weer te gee, telkens ook 'ander' is: "Painting, writing poetry - these are acts of appropriation. (...) You become who and what you paint ..." (Breytenbach, 1991:76).

Op hierdie manier is elke skildery 'n selfportret, en kan Breytenbach (1991:76-77) sê: "Every portrait - landscape or poem or other depiction - is a selfportrait. This is so because depiction is recognition and exposition." Dit wat jy sien of ervaar, word onherroeplik deel van jouself, en die bewus wees van hierdie voortdurende transformasieproses kan alleenlik in terme van beeld of metafoor uitgedruk word (Breytenbach, 1991:77). Vandaar die drang na skryf en skilder, by uitstek die kunsvorme wat met die Zen geassosieer word, en natuurlik met Breytenbach. In die poësie word dit byvoorbeeld:

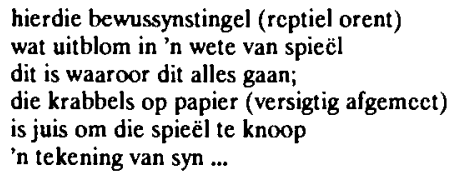

(Breytenbach, 1983 b:35.)

Maar miskien word dit die duidelikste verbeeld in sy skilderkuns waar Zen-Boeddhistiese selfloosheid impliseer dat die grense van tyd en ruimte deurbreek word; 'ek' is telkens uniek maar telkens paradoksaal één met die kunstenaar, die objek van uitbeelding én die kyker.

Want die spieël is nie verniet 'n sentrale metafoor by Breytenbach nie (vergelyk Ferreira, 1988:1-10). Die doek of vel papier word nie net spieël vir selfbewussyn as "die tydelike som van my indrukke" nie, maar word aan die kyker voorgehou as spieël van sy eie condition humaine. Die kyker of leser word sodoende nie net gekonfronteer met sy eie toestand van illusionêre ego nie, maar ook genooi tot die (Boeddhistiese) deurbreking van subjek-objekpolariteit. As deelnemer aan hierdie proses word hy of sy as 'ander' in 'n paradoksale verhouding tot die kunstenaar/skrywer geplaas: enersyds as spieëlbeeld met hom geïntegreer, maar andersyds ook altyd sy noodsaaklike teenoorgestelde en teenpool.

Die kunswerk of teks gaan dus geensins oor 'n daarstelling van betekenis nie, maar oor die ervaring van 'n wesenstoestand: "If you can look without projecting a meaning you will be confronted head-on by an embodiment of being" (Breytenbach, 1991:79). Die kunswerk of teks is die instrument waardeur die transformerende verhouding tussen kyker en kunstenaar, leser en skrywer bewerkstellig en ervaar word; die "story which will be unique and different for each person coming into contact with it" (Breytenbach, 1991:76). Binne die konteks van die Zen-Boeddhisme verbeeld die voortdurende interafhanklikheid tussen kunstenaar, objek van uitbeelding en kyker, (wat andersins as konvensionele teenpole van mekaar optree), die transendering van dualiteit. Die bevrydende "gly en hekel tussen vuur en droom" van die kommunikasiehandeling is soos "stofwisseling" tussen leser, teks en skrywer omdat "elke uur vanaf die oudste teken reeds / 'n ritus (is) van neem en gee - " (Breytenbach, 1983b:33). Sodoende word die kunswerk- of gedig-as-proses 'n metafoor van Satori; momentele integrasie van pole wat deur middel van selfloosheid bereik word. 


\section{Bibliografie}

Abe, M. 1985. Zen and Westem Thought. Honolulu : University of Hawaii Press.

Alberti, Rafael 1988. The Penguin Book of Spanish Verse. London : Penguin.

Blyth, R.H. 1978. Zen and Zen Classics. New York : Random House.

Botha, E. 1988. ... 'n skone spieël, gekraak, gebreek... : Breyten Breytenbach se "bespieëlende not as van 'n roman". Mouroir 1983, as versplintering van 'n tradisie. Tydskrif vir Literatuurwetenskap, VIII :5-22, April.

Breytenbach, Breyten 1976. Voetskrif. Johannesburg : Perskor.

Breytenbach, Breyten 1983a. Mouroir. Emmarentia : Taurus.

Breytenbach, Breyten 1983b. ("Yk"). Emmarentia : Taurus.

Breytenbach, Breyten 1983c. Eklips. Emmarentia : Taurus.

Breytenbach, Breyten 1983d. End Papers. London : Faber and Faber.

Breytenbach, Breyten 1984a. Buffalo Bill. Emmarentia : Taurus.

Breytenbach, Breyten 1984b. The true confessions of an albino terrorist. London: Faber and Faber.

Breytenbach, Breyten 1985. Lewendood. Emmerentia: Taurus.

Breytenbach, Breyten 1987. Boek (deel een). Emmarentia : Taurus.

Breytenbach, Breyten 1990a. All one horse. Emmarentia : Taurus.

Brcytenbach, Breyten 1990b. Soos die So. Emmarentia : Taurus.

Breytenbach, Breyten 1991. Hart-lam. 'n Leerboek. Emmarentia : Taurus.

Breytenbach, Breyten 1992. Radio-onderhoud. SAUK. Febr. 9.

Dumoulin, H. 1963. A History of Zen Buddhism. Translated from the German by Paul Peachey. Boston : Bacon Press.

Ferreira, J. 1988. Ekstratekstuele relasies van "spieël" in die poësie van Breyten Breytenbach. Literator, 9 (3):1-10. November.

Golz, H.G. 1989. The Concept of "Self" in Breyten Breytenbach's Mouroir. Mirromotes of a Novel. Ongepubliscerde M A.-verhandeling, Universiteit van Aachen, Duitsland.

Hcrigel, E. 1953. Zen in the Art of Archery. London : Routledge and Kegan Paul.

Hofmeyr, J. 1991. (i) Buddhism. (ii) The Religions of China. In: De Gruchy, J.W. \& Prozesky, M. (eds). A Southern African Guide to World Religions. Cape Town : David Phillip Publishers. pp. 84-118.

Hoover, T. 1988. Zen Culture. London : Routledge.

Kalupahana, D. 1992. A History of Buddhist Philosophy. Honolulu : University of Hawaii Press.

Leenhardt, J. 1987. Retrospective provisoire de Breyten Breytenbach: 1965-1986. Galerie de la ville de Montreuil.

Sienaert, M. 1991. Aspckte van Lacaniaanse psigo-analise as kode by 'n semiotiese lesing van Breytenbach se ("Yk"). Literator, 12 (2):23-33. Aug

Suzuki, D.T. 1957. An Introduction to Zen Buddhism. London : Rider and Company.

Versfeld, M. 1991. Sum. Selected Works. Cape Town: The Carrefour Press.

Watts, A.W. 1957. The Way of Zen. London: Thames and Hudson.

Watts, A.W. 1975. Tao, the Watercourse Way. London: Penguin books.

Williams, P. 1989. Mahayana Buddhism. The Doctrinal Foundations. London : Routledge.

\section{Universiteit van Durban-Westville}


